\title{
Improving oral and dental health through counseling to elementary school students in Jember
}

\author{
Tantin Ermawati ${ }^{a, 1}{ }^{*}$, Ristya Widi Endah Yani a,2, Mei Syafriadi a,3 \\ ${ }^{a}$ Faculty of Dentistry, University of Jember, Jl. Kalimantan, Sumbersari, Jember, East Java 68121, Indonesia \\ ${ }^{1}$ tantin.ermawati@gmail.com, ${ }^{2}$ ristya_widi@yahoo.com, ${ }^{3}$ didiriadihsb.fkg@unej.ac.id \\ * Corresponding author
}

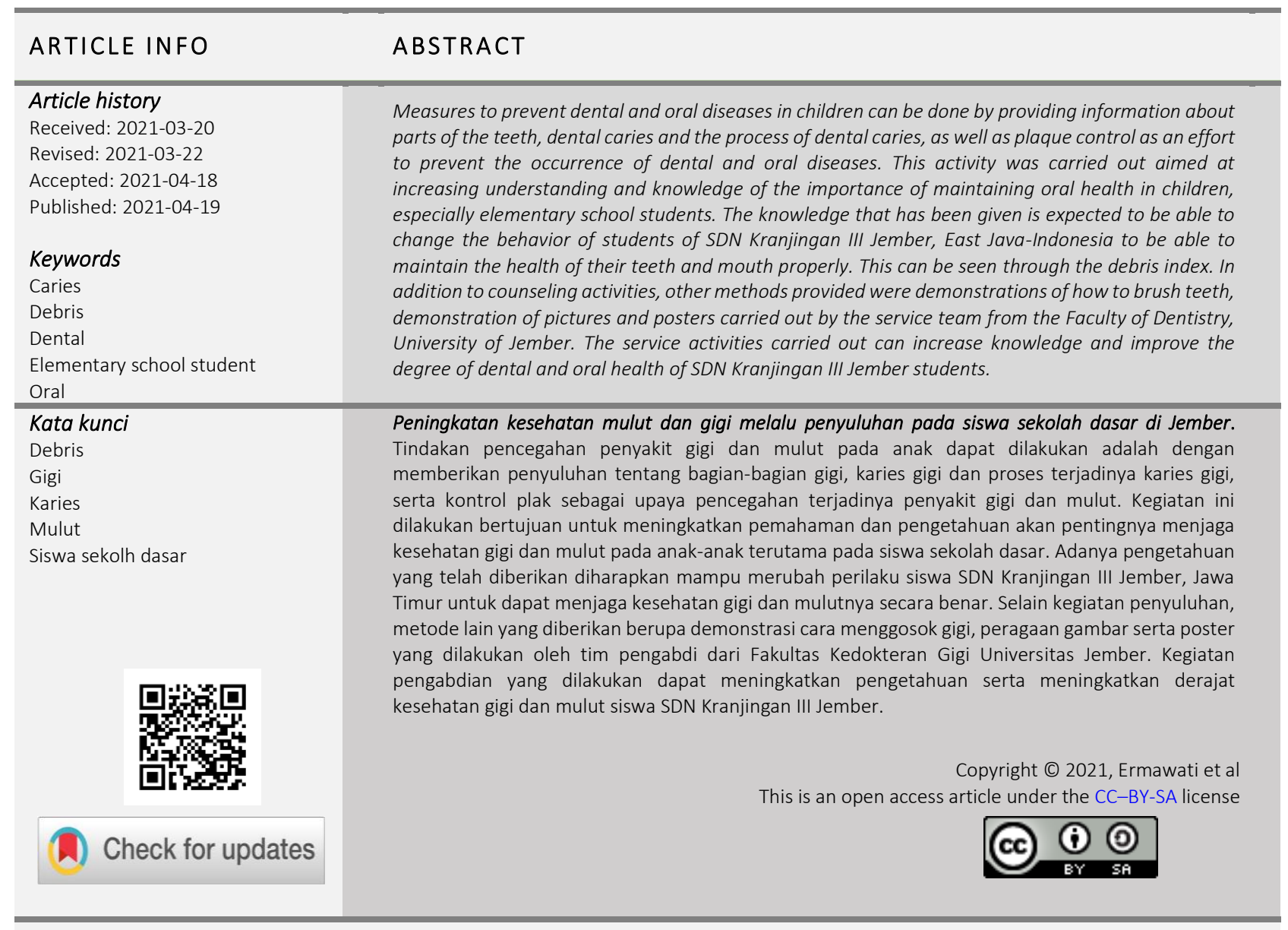

How to cite: Ermawati, T., Yani, R. W. E., \& Syafriadi, M. (2021). Improving oral and dental health through counseling to elementary school students in Jember. Journal of Community Service and Empowerment, 2(1), 1-7. doi: https://doi.org/10.22219/jcse.v2i1.16034

\section{PENDAHULUAN}

Kesehatan gigi dan mulut adalah suatu keadaan dimana gigi dan mulut berada dalam kondisi bebas dari bau mulut, kesehatan gusi dan gigi, tidak adanya plak dan karang gigi, gigi dalam keadaan putih dan bersih, serta memiliki kekuatan yang baik (Adnyani et al., 2016; Jaini, 2019; Mardelita et al., 2018). Karies gigi adalah suatu penyakit infeksi dalam rongga mulut yang merupakan penyebab utama kehilangan gigi pada anak-anak dan orang dewasa. Lubang yang terlihat pada gigi secara klinis (karies) merupakan proses akhir dari penyakit ini. Rerata waktu dari mulai terjadinya lesi awal hingga terjadinya lubang gigi pada anak-anak adalah sekitar $18 \pm 6$ bulan. Karies gigi juga masih menjadi masalah kesehatan anak. Dari penelitian yang dilakukan Febriana di lima wilayah di DKI Jakarta tahun 2007, diketahui prevalensi Early Childhood Caries (ECC) anak usia di bawah tiga tahun di DKI Jakarta 52.7\% dengan rata-rata skor def-t 2.85. Laporan nasional 
Riskesdas 2007 menyatakan bahwa prevalensi penduduk dengan penyakit gigi-mulut berdasarkan karakteristik responden pada anak usia < 1 tahun adalah 1.1\%, anak usia 1-4 tahun adalah 6.9\% dan anak usia 5-9 tahun adalah 21.6\% (Yulita et al., 2008).

Karies gigi masih menjadi masalah kesehatan anak. Organisasi Kesehatan Dunia atau World Health Organisation (WHO) menyatakan, angka kejadian karies gigi pada anak 60\%-90\%. Survey yang dilakukan oleh Departemen Kesehatan Republik Indonesia pada pelita III dan IV menunjukkan prevalensi penduduk Indonesia yang menderita karies gigi sebesar 80\%, dimana 90\% diantaranya adalah anak balita (Mukhbitin, 2018). Hasil Riset Kesehatan Dasar (Riskesdas) 2018 memperlihatkan prevalensi gigi berlubang pada anak usia dini masih sangat tinggi yaitu sekitar 93\%. Artinya hanya $7 \%$ anak Indonesia yang bebas dari karies gigi (Kemenkes RI Dirjen P2P, 2020).

Federation Dental International (FDI) dan WHO menargetkan bahwa minimal 50\% anak usia 5-6 tahun harus bebas dari karies gigi (Kemenkes RI Dirjen P2P, 2020). Hal ini juga sejalan dengan tujuan dengan Sustainable Development Goals (SDGs) poin ke-3, yaitu Good health and well-being yang dapat tercapai melalui jalur 3.7, yaitu "universal access to sexual and reproductive care, family planning and education" (Wening, 2018). Pada poin ke-3, yaitu menggalakkan hidup sehat dan mendukung kesejahteraan untuk semua usia, termasuk juga di dalamnya adalah menjaga kesehatan gigi dengan gosok gigi (Defi, 2017).

Pendidikan kesehatan atau penyuluhan kesehatan adalah semua kegiatan untuk memberikan dan atau meningkatkan pengetahuan, sikap, dan praktek masyarakat dalam memelihara dan meningkatkan kesehatan mereka sendiri, sehingga mempunyai kemampuan dan kebiasaan untuk berperilaku hidup sehat di bidang kesehatan gigi dan mulut(Sari, 2013; Widodo, 2016). Hal ini dilakukan dengan tujuan meningkatkan pengetahuan masyarakat tentang kesehatan, khususnya kesehatan gigi dan mulut (Al-Qahtani et al., 2020; Jatmika \& Maulana, 2018; Lawal \& Taiwo, 2014; Sanadhya et al., 2014; Shah et al., 2016).

Tingkat pelayanan kesehatan gigi, dapat dilakukan berdasarkan 5 tingkat pencegahan dari leavel and clark sebagai berikut: (1) Promosi kesehatan, misalnya dengan memilih makanan yang menyehatkan gigi, mengatur pola makan yang mengandung gula. (2) Perlindungan khusus, misalnya pembersihan karang gigi, menyikat gigi setelah makan, topikal aplikasi flour. (3) Diagnosis dini dan pengobatan Segera, misalnya pemeriksaan gigi dengan sinar-X secara berkala, penambalan gigi yang baru terkena karies, penambalan fissure yang terlalu dalam. (4) pererawatan pulpa terbuka, misalnya pulp capping, perawatan saluran akar, pencabutan gigi. (5) Rehabilitasi, misalnya membuat gigi tiruan(Herijulianti et al., 2002).

Berbagai upaya dilakukan oleh pemerintah untuk menurunkan prevalensi karies gigi pada anak di Indonesia khususnya pada anak usia sekolah dasar. Sejalan dengan program yang dicanangkan oleh pemerintah maka salah satu upaya yang dilakukan oleh dosen fakultas kedokteran gigi melalui kegiatan Tridharma perguruan tinggi berupa pengabdian kepada masyarakat yakni dengan memberikan penyuluhan tentang kesehatan gigi dan mulut khususnya pencegahan karies gigi pada anak sekolah dasar.

Pencegahan karies gigi dapat dilakukan melalui tindakan promotif dan preventif (Al-Qahtani et al., 2020; Antonio et al., 2005; Jepsen et al., 2017). Kegiatan yang dapat dilakukan adalah dengan promosi kesehatan (penyuluhan dan sikat gigi bersama) yang hasilnya dapat dilihat dengan mengukur indeks debris (Hermawan et al., 2015; Jaini, 2019; Mardelita et al., 2018; Mukhbitin, 2018; Niakurniawati \& Imran, 2021; Nurizza et al., 2020). Beberapa studi terdahulu menunjukkan bahwa prevalensi karies meningkat seiring dengan meningkatnya umur, oleh karena itu penting untuk memberikan pengetahuan tentang pencegahan terhadap karies gigi lebih dini. Sehubungan dengan itu, SDN Kranjingan III adalah salah satu sekolah dasar yang termasuk dalam wilayah kerja Puskesmas Gladak Pakem. SDN Kranjingan III terletak di pinggiran kota Jember (kira-kira $10 \mathrm{Km}$ dari pusat kota). Untuk mencapai kesehatan gigi dan mulut yang optimal, maka harus dilakukan tindakan pencegahan sedini mungkin. Salah satu tindakan pencegahan yang paling efektif adalah penyuluhan. Hal ini yang mendorong pengabdi untuk melakukan kegiatan preventif berupa penyuluhan pada siswa SDN Kranjingan III kelas IV dan V.

Berdasarkan uraian tersebut kegiatan ini bertujuan untuk meningkatkan pengetahuan, sikap, dan praktek dalam memelihara dan meningkatkan kesehatan gigi dan mulut siswa Sekolah Dasar Kranjingan III Jember yang dapat dilihat dari indeks debris. Kegiatan ini memberikan kontribusi atau manfaat kepada masyarakat, yaitu (1) Meningkatkan kesadaran anak sekolah dasar akan pentingnya menjaga kesehatan gigi dan mulut sejak dini untuk mencegah timbulnya penyakit gigi dan mulut. (2) Para siswa dapat mengubah sikap dan perilaku dalam menjaga kesehatan gigi dan mulut sehingga mampu berprilaku sesuai dengan pola kesehatan yang diharapkan. (3) Siswa dapat mengetahui dan mempraktekkan tindakan pencegahan penyakit gigi dan mulut. Kegiatan ini pun dapat memberi informasi yang berkaitan dengan kajian tentang pengetahuan, sikap dan tindakan anak sekolah dasar tentang penyakit gigi dan mulut.

\section{METODE}

\section{Bentuk kegiatan}

Pada kegiatan ini, upaya pencegahan karies diberikan dalam bentuk penyuluhan (ceramah) mengenai fungsi gigi, penyebab dan mekanisme terjadinya penyakit gigi dan mulut, upaya pencegahannya, dan akibat yang ditimbulkan apabila 
tidak dilakukan perawatan. Penyuluhan dibantu dengan alat peraga berupa gambar/poster dan model gigi serta demonstrasi dan sesi tanya jawab. Khalayak sasaran adalah siswa sekolah dasar di SD Kranjingan III Jember.

\section{Khalayak Sasaran dan Tempat}

Kegiatan dilaksanakan di SDN Kranjingan III yang beralamat di Jl. Ajisaka 88 Kranjingan Sumbersari Jember Jawa Timur (Gambar 1). Khalayak sasaran adalah siswa kelas IV dan V beserta para guru. SDN Kranjingan III terletak di desa Kranjingan, Kecamatan Sumbersari yang merupakan salah satu kecamatan yang ada di wilayah Kota Jember. Penduduk mayoritas desa Kranjingan adalah Madura. Lokasi SDN Kranjingan III berjarak \pm 5 km dari Fakultas Kedokteran Gigi Universitas Jember dengan jarak tempuh sekitar 25 menit menggunakan kendaraan motor.

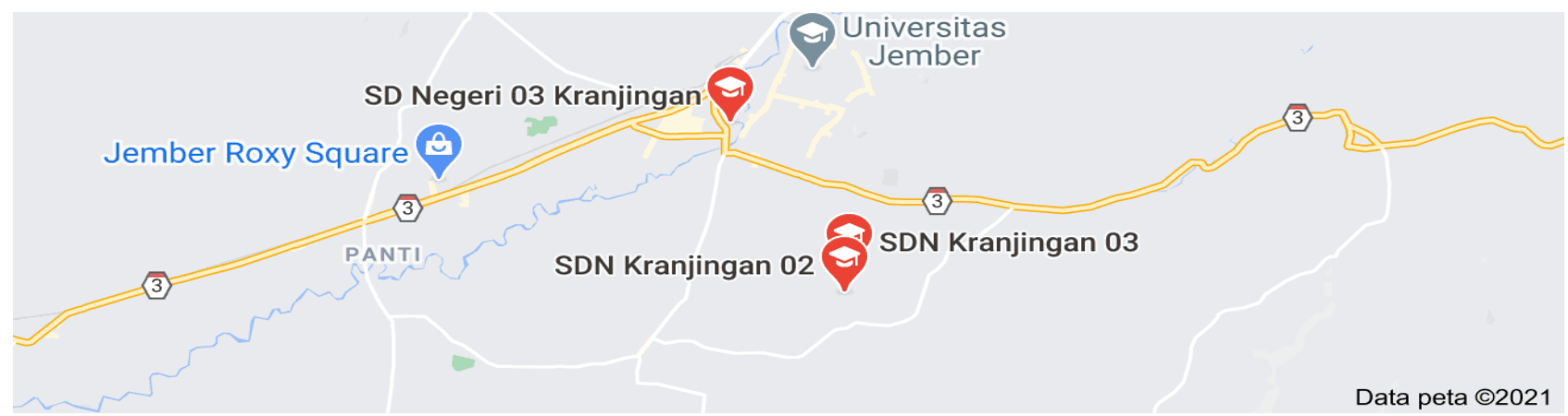

Gambar 1. Lokasi SDN Kranjingan III berdasar Google Map

\section{Pelaksanaan}

Dalam kegiatan ini, bentuk pelaksanaan yang digunakan adalah memberikan pengetahuan dan wawasan tentang kesehatan gigi dan mulut dengan cara penyuluhan, peragaan dengan poster dan tanya jawab. Materi yang disampaikan adalah mengenai fungsi gigi, penyebab dan mekanisme terjadinya penyakit gigi dan mulut, upaya pencegahannya, dan akibat yang ditimbulkan bila tidak dilakukan perawatan.

\section{HASIL DAN PEMBAHASAN}

Kegiatan pengabdian yang dilakukan berupa penyuluhan kesehatan gigi dan mulut pada siswa sekolah dasar di SDN Kranjingan III di Jl. Kranjingan Sumbersari Jember berjalan dengan baik dan lancar. Dokumentasi kegiatan sebagaimana disajikan pada Gambar 2.

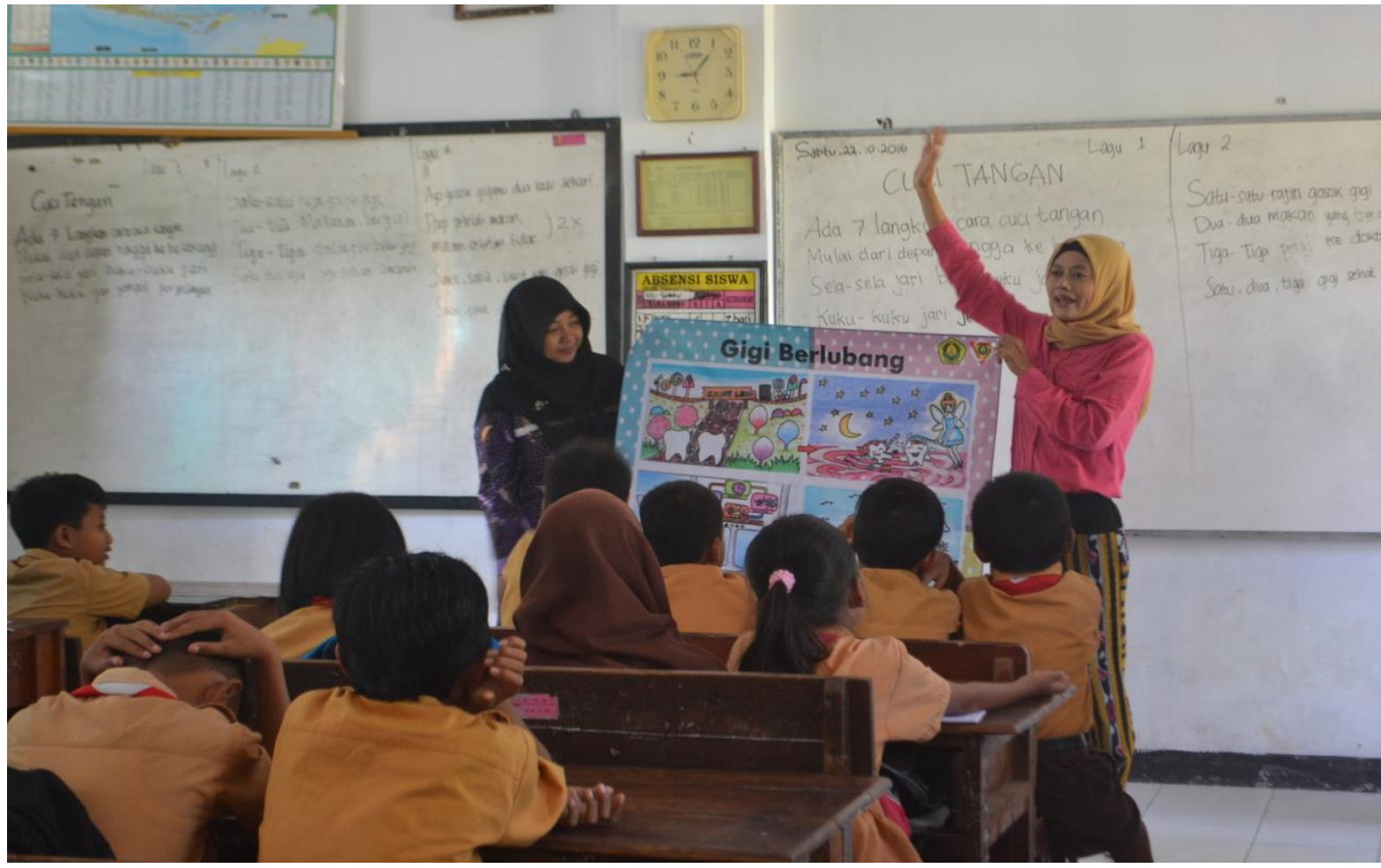

Gambar 2. Penyampaian materi oleh tim pengabdi kepada siswa 
Kegiatan ini dilakukan oleh pengabdi yang berasal dari Fakultas Kedokteran Gigi Universitas Jember, hal ini merupakan salah satu wujud pengamalan dari tugas seorang pendidik dalam melaksanakan Tridharma Perguruan Tinggi. Wujud pengamalan tersebut berupa pendidikan, penelitian dan pengabdian kepada masyarakat.

Proses penyuluhan berlangsung lancar dan mendapatkan respon yang baik dari siswa (berjumlah 76 orang, dari kelas 4 dan 5) maupun guru. Para siswa mendengarkan dengan seksama terhadap materi-materi penyuluhan, yaitu (1) gigi dan bagian-bagiannya, (2) kesehatan gigi dan mulut terutama proses terjadinya karies gigi, dan (3) kontrol plak (prosedur yang dilakukan untuk menghilangkan dan mencegah penumpukan plak serta deposit lunak dari permukaan gigi dan gingiva sekitarnya. Siswa sangat antusias karena materi tersebut selama ini belum mereka ketahui. Selain itu materi yang disampaikan menjadi sangat menarik karena didukung dengan adanya gambar dan poster untuk memudahkan para siswa mengingat. Setelah pemberian materi dan peragaan cara menggosok gigi yang benar dilakukan diskusi tanya jawab antara siswa dan tim pengabdi. Diskusi dan tanya jawab yang terjadi sangat aktif sehingga siswa merasa senang dan menambah pengetahuan mereka tentang bagaimana cara menjaga kebersihan gigi dan mulut secara benar untuk mencegah terjadinya karies gigi. Antusiasme siswa sebagaimana ditunjukkan pada Gambar 3.

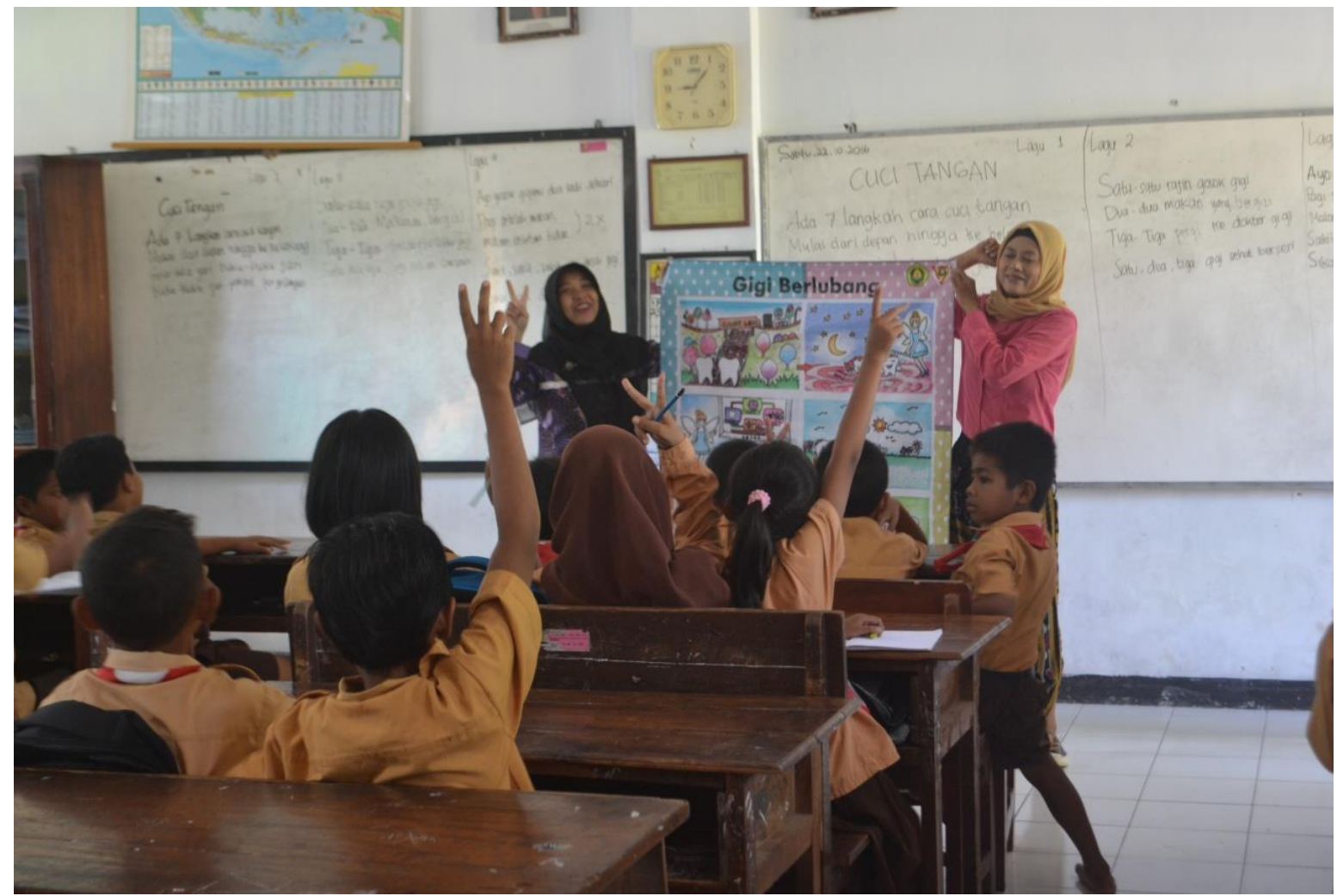

Gambar 3. Bentuk antusiasme siswa selama kegiatan

Selain penyuluhan yang diberikan kepada siswa, maka orangtua dan guru yang hadir dalam kegiatan tersebut diberikan kesempatan oleh pemateri untuk bertanya dan berkonsultasi seputar kesehatan gigi dan mulut terutama masalah karies gigi. Upaya ini dilakukan untuk memberikan modal pengetahuan kepada orangtua tentang pentingnya kesehatan gigi dan mulut dalam membimbing putra/putrinya dalam menjaga kesehatan gigi dan mulut di rumah.

Kegiatan ini juga melibatkan orang tua, karena peran mereka sangat penting dalam promosi kesehatan gigi dan mulut. Menurut Nurizza et al (2020), peran orangtua terhadap skor debris index siswa SD sangat penting. Sejalan dengan itu, Kristianto et al (2018) menegaskan bahwa promosi kesehatan, merupakan penunjang yang sangat mendukung peningkatan kemampuan masyarakat dalam memelihara kesehatan gigi dan mulut.

Untuk mengukur keberhasilan kegiatan pengabdian ini, maka tim melakukan pemeriksaan indeks Debris sebelum dan sesudah promosi kesehatan (penyuluhan). Adapun karakteristik responden (peserta) sebagaimana disajikan pada Tabel 1 , sementara hasil pemeriksaan indeks Debris disajikan pada Tabel 2.

Tabel 1. Distribusi karakteristik responden berdasarkan jenis kelamin

\begin{tabular}{lll}
\hline Jenis Kelamin & Jumlah $(\mathrm{n})$ & Persentase (\%) \\
\hline Laki- laki & 34 & 44.7 \\
Perempuan & 42 & 55.2 \\
\hline Total & 76 & 100 \\
\hline
\end{tabular}


Tabel 2. Hasil pemeriksaan indeks debris sebelum dan sesudah promosi kesehatan (penyuluhan)

\begin{tabular}{ccccccccc}
\hline \multirow{2}{*}{ Indeks Debris } & \multicolumn{3}{c}{ Sebelum promosi kesehatan } & \multicolumn{4}{c}{ Sesudah promosi kesehatan } \\
\cline { 2 - 9 } & Laki-laki & Perempuan & $\mathbf{n}$ & $\%$ & Laki-laki & Perempuan & $\mathbf{n}$ & $\%$ \\
\hline Baik & 0 & 9 & 9 & 11.8 & 8 & 17 & 25 & 32.8 \\
Sedang & 7 & 4 & 11 & 14.5 & 21 & 30 & 51 & 67.1 \\
Buruk & 36 & 20 & 56 & 73.6 & 0 & 0 & 0 & 0 \\
\hline Total & & & 76 & 100 & & 75 & 100 \\
\hline
\end{tabular}

Berdasarkan hasil pemeriksaan indeks debris (sebelum dan sesudah kegiatan) sebagaimana yang disajikan pada Tabel 2 dapat dinyatakan bahwa kegiatan pengabdian yang dilakukan dapat meningkatkan pengetahuan serta meningkatkan derajat kesehatan gigi dan mulut siswa SDN Kranjingan III Jember. Capaian kegiatan ini sejalan dengan Hermawan et al (2015) bahwa kegiatan promosi kesehatan tentang menyikat gigi memberikan perbedaan yang bermakna antara indeks debris pada murid SD.

Kegiatan ini pun melibatkan guru SD. Peran guru sangatlah penting karena hubungan guru dengan anak di lingkungan sekolah terjalin dengan akrab dan dekat, sehingga akan dapat membantu dalam penyampaian pesan perilaku hidup sehat (Mardhiati, 2019). Siswa SD menaruh rasa percaya yang tinggi kepada gurunya, sehingga guru dapat berperan dalam mengajak dan memberikan pendidikan kesehatan gigi dan mulut kepada siswa secara lebih intens (Arianto, 2017; Astuti, 2013; Lestari \& Indarjo, 2016; Nugraheni et al., 2018).

Di akhir sesi, dilakukan foto bersama yang diikuti dengan semangat oleh para siswa dan guru (Gambar 4). Momen ini juga digunakan untuk menguatkan pesan kepada siswa agar mereka rajin memelihara kesehatan gigi dan mulut sebagaimana yang telah disuluhkan.

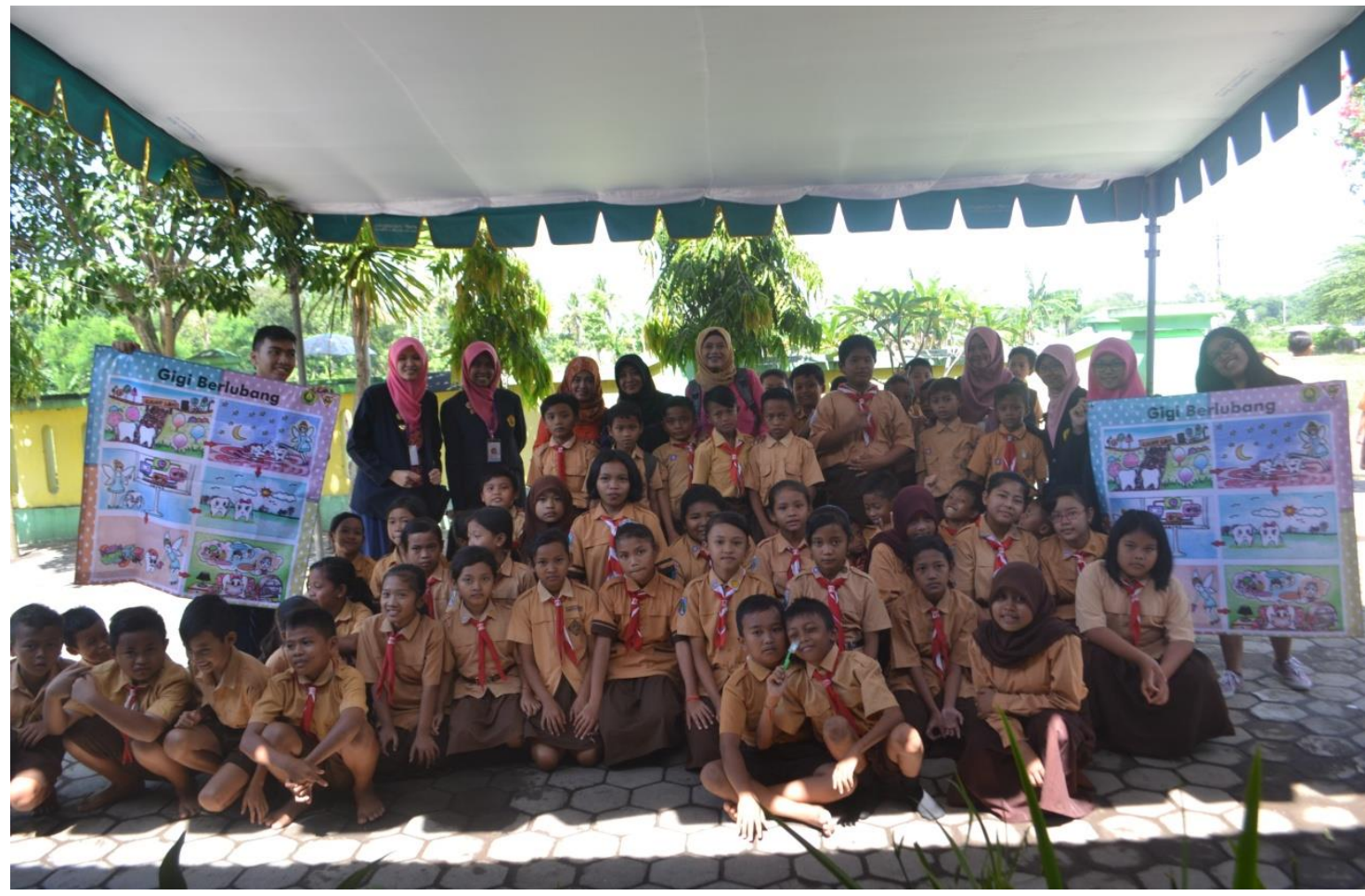

Gambar 4. Foto bersama diakhir kegiatan dan penguatan pesan kepada siswa.

Setelah dilakukan evaluasi terhadap kegiatan yang telah dilakukan, maka perlu adanya masukan bagi pihak sekolah SDN Kranjingan III untuk dibentuk adanya program usaha kesehatan gigi sekolah (UKGS). Hal ini bertujuan untuk menekan tingginya angka karies gigi pada siswa sekolah dasar. Menurut (Lestari \& Indarjo, 2016), UKGS bertujuan memelihara dan kesehatan gigi mulut siswa SD yang dapat didukung dengan tindakan kuratif perawatan gigi dan mulut. Adapun kegiatan UKGS, misalnya pendidikan dan pelayanan kesehatan serta kegiatan pembinaan sekolah yang sehat.

\section{KESIMPULAN}

Kegiatan pengabdian yang dilakukan dapat meningkatkan pengetahuan serta meningkatkan derajat kesehatan gigi dan mulut siswa SDN Kranjingan III Jember. Berdasar kegiatan ini, diperlukan pemeriksaan dini deteksi karies pada siswa sekolah dasar. Kegiatan promotif dan preventif yang berkelanjutan perlu dilakukan di SDN Kranjingan III Jember, guna 
menurunkan prevalensi karies gigi pada siswa. Untuk mendukung kegiatan tersebut, pihak sekolah SDN Kranjingan III perlu segera membentuk program usaha kesehatan gigi sekolah (UKGS), hal ini bertujuan untuk menekan tingginya angka karies gigi pada siswa sekolah dasar.

Berdasarkan refleksi kegiatan ini, maka kami merekomendasikan bahwa perlu perawatan karies gigi dan penyakit periodontal pada siswa SDN Kranjingan III Jember oleh dokter gigi agar kerusakan yang terjadi tidak semakin parah. Kerjasama yang baik antara sekolah dan dokter gigi di puskesmas terdekat juga penting dilakukan sebagai pelayan kesehatan dalam melakukan perawatan kesehatan gigi dan mulut.

\section{UCAPAN TERIMA KASIH}

Terima kasih disampaikan kepada Rektor Universitas Jember, Dekan Fakultas Kedokteran Gigi Universitas Jember, Kepala Sekolah dan para orang tua siswa SDN Kranjingan III Jember yang telah mendukung kegiatan pengabdian ini.

\section{REFERENSI}

Adnyani, N. P., Made, I., \& Artawa, B. (2016). Pengaruh Penyakit Gigi Dan Mulut Terhadap Halitosis. Jurnal Kesehatan Gigi, 4(1), 24-28.

Al-Qahtani, S. M., Razak, P. A., \& Khan, S. D. A. A. (2020). Knowledge and practice of preventive measures for oral health care among male intermediate schoolchildren in abha, Saudi Arabia. International Journal of Environmental Research and Public Health, 17(3), 703. https://doi.org/10.3390/ijerph17030703

Antonio, A. G., Maia, L. C., Vianna, R. B. de C., \& Quintanilha, L. E. L. P. (2005). Preventive strategies in oral health promotion. Ciência \& Saúde Coletiva, 10(suppl), 279-286. https://doi.org/10.1590/s1413-81232005000500028

Arianto, A. (2017). Peran Orang Tua, Teman, Guru, Petugas Kesehatan Terhadap Perilaku Menggosok Gigi Pada Siswa Sekolah Dasar di Kecamatan Sumberejo. Jurnal Analis Kesehatan, 2(2), 270-275.

Astuti, N. R. (2013). Promosi Kesehatan Gigi Dan Mulut Dengan Metode Ceramah Interaktif Dan Demonstrasi Disertai Alat Peraga Pada Guru Sekolah Dasar Sebagai Fasilitator. Insisiva Dental Journal: Majalah Kedokteran Gigi Insisiva, 2(2), 16-25.

Defi, R. (2017). Gerakan Cinta Gigiku (Gertagi) Sejak Dini di Wilayah Kerja Puskesmas Bugangan. UPTD PUSKESMAS BUGANGAN DINAS KESEHATAN KOTA SEMARANG. https://bpsdmd.jatengprov.go.id/eproper/cetakinovasi/?nourut=1062

Herijulianti, E., Indriani, T. S., \& Artini, S. (2002). Pendidikan kesehatan gigi (M. Ester (ed.)). EGC.

Hermawan, H., Umboh, A., \& Mintjelungan, C. (2015). Indeks debris sebelum dan sesudah dilakukan promosi kesehatan tentang menyikat gigu pada murid SD Negeri Poigar. Jurnal E-GiGi, 3(2), 521-526.

Jaini, R. E. (2019). Gambaran Status Karies Gigi Pada Masyarakat Pesisir yang Mengkonsumsi Air Sumur Gali dan Air Isi Ulang di Desa Pematang Kasih Kecamatan Pantai Cermin Kabupaten Pantai Cermin Kabupaten Serdang Bedaga. Politeknik Kesehatan Kemenkes RI Medan.

Jatmika, S. E. D., \& Maulana, M. (2018). Dental and Oral Health Education for Elemetary School Students through Patient Hygiene Performance Index Indicator. International Journal of Evaluation and Research in Education (IJERE), 7(4), 259. https://doi.org/10.11591/ijere.v7i4.14856

Jepsen, S., Blanco, J., Buchalla, W., Carvalho, J. C., Dietrich, T., Dörfer, C., Eaton, K. A., Figuero, E., Frencken, J. E., Graziani, F., Higham, S. M., Kocher, T., Maltz, M., Ortiz-Vigon, A., Schmoeckel, J., Sculean, A., Tenuta, L. M. A., van der Veen, M. H., \& Machiulskiene, V. (2017). Prevention and control of dental caries and periodontal diseases at individual and population level: consensus report of group 3 of joint EFP/ORCA workshop on the boundaries between caries and periodontal diseases. Journal of Clinical Periodontology, 44, S85-S93. https://doi.org/10.1111/jcpe.12687

Kemenkes RI Dirjen P2P. (2020). Survey Menunjukkan Kebiasaan Gosok Gigi Menurun Saat Pandemi COVID-19. In Kementerian Kesehatan RI (Vol. 5, Issue 1, p. 1). https://www.kemkes.go.id/article/view/19093000001/penyakitjantung-penyebab-kematian-terbanyak-ke-2-di-indonesia.html

Kristianto, J., Priharti, D., \& Abral, A. (2018). Efektifitas Peyuluhan Kesehatan Gigi Dan Mulut Dengan Media Video Melalui WhatsApp Dalam Meningkatkan Derajat Kesehatan Gigi Dan Mulut Di Panti Asuhan Yos Sudarso Jakarta. Quality : Jurnal Kesehatan, 12(1), 8-13. https://doi.org/10.36082/qjk.v12i1.24

Lawal, F. B., \& Taiwo, J. O. (2014). An audit of school oral health education program in a developing country. Journal of International Society of Preventive \& Community Dentistry, 4(Suppl 1), S49-S55. https://doi.org/10.4103/22310762.144600

Lestari, D. R., \& Indarjo, S. (2016). Evaluasi Penerapan Manajemen UKGS Dalam Perilaku Perawatan Gigi dan Mulut Siswa Sekolah Dasar. JHE (Journal of Health Education), 1(2), 8-11.

Mardelita, S., Sukendro, S. J., \& Karmawati, I. A. (2018). Pelayanan Asuhan Kesehatan Gigi dan Mulut Individu: Bahan ajar keperawatan gigi. Kementerian Kesehatan Republik Indonesia. 
Mardhiati, R. (2019). Guru PAUD: Pendidikan Perilaku Hidup Bersih Dan Sehat (PHBS) Anak Usia Dini. Ikra-Ith Abdimas, 2(3), 133-141.

Mukhbitin, F. (2018). Gambaran kejadian karies gigi pada siswa kelas 3 MI Al-Mutmainnah. Jurnal Promkes, 6(2), 155166.

Niakurniawati, N., \& Imran, H. (2021). Asuhan kesehatan gigi dan mulut dalam penurunan debris index pada anak berkebutuhan khusus di SLB YPAC Banda Aceh. Jurnal Kreativitas Pengabdian Kepada Masyarakat (PKM), 4(1), 226-233.

Nugraheni, H., Sunarjo, L., Wiyatini, T., DIII Keperawatan Gigi, P., \& Keperawatan Gigi Poltekkes Kemenkes Semarang, J. (2018). Peran Guru Dalam Promosi Kesehatan Gigi Dan Mulut Di Sekolah. Jurnal Kesehatan Gigi, 05(2), $13-21$. http://ejournal.poltekkes-smg.ac.id/ojs/index.php/jkg/article/view/3857

Nurizza, E., Isnanto, I., \& Purwaningsih, E. (2020). Pengaruh Peran Orangtua Terhadap Debris Index Score Siswa Inklusi Sdn Pakis Viii Surabaya 2020. Journal of Oral Health Care, 8(1), 8-17.

Sanadhya, Y. K., Thakkar, J. P., Divakar, D. D., Pareek, S., Rathore, K., Yousuf, A., Ganta, S., Sobti, G., Maniar, R., Asawa, K., Tak, M., \& Kamate, S. (2014). Effectiveness of oral health education on knowledge, attitude, practices and oral hygiene status among 12-15-year-old schoolchildren of fishermen of Kutch district, Gujarat, India. International Maritime Health, 65(3), 99-105. https://doi.org/10.5603/imh.2014.0022

Sari, I. P. T. P. (2013). Pendidikan Kesehatan Sekolah Sebagai Proses Perubahan Perilaku Siswa. Jurnal Pendidikan Jasmani Indonesia, 9(2), 141-147. https://journal.uny.ac.id/index.php/jpji/article/viewFile/3017/2510

Shah, N., Mathur, V. P., Kathuria, V., \& Gupta, T. (2016). Effectiveness of an educational video in improving oral health knowledge in a hospital setting. Indian Journal of Dentistry, 7(2), 70-75. https://doi.org/10.4103/0975962X.184646

Wening, G. R. S. (2018). Model Prediksi Perilaku Kesehatan Gigi Ibu Hamil Berbasis Kemampuan Literasi Dalam Upaya Pencegahan Karies Gigi Anak. Universitas Airlangga.

Widodo, B. (2016). Pendidikan Kesehatan Dan Aplikasinya di SD/MI. Madrasah, 7(1), 12. https://doi.org/10.18860/jt.v7i1.3306

Yulita, I., Elly, D., \& Victrix, A. A. (2008). Air Susu Ibu Dan Karies Gigi Sulung. Jurnal Health Quality, 4(1), 69-76. http://poltekkesjakarta1.ac.id/file/dokumen/4Jurnal_Ita_Yulita.pdf 